\title{
Optimizing Soil Disinfestation Procedures for Fresh Market Tomato and Pepper Production
}

\author{
D. O. Chellemi, USDA, ARS, U.S. Horticultural Research Laboratory, 2001 South Rock Rd., Fort Pierce, FL 34945; \\ and J. Mirusso, Mirusso Enterprises, Delray Beach, FL
}

\begin{abstract}
Chellemi, D. O., and Mirusso, J. 2006. Optimizing soil disinfestation procedures for fresh market tomato and pepper production. Plant Dis. 90:668-674.

Combinations of soil fumigation with a mixture of 1,3-dichloropropene (1,3-D) plus chloropicrin (Pic) and soil solarization for 7 days were evaluated under different plastic films and sequences of application for their effects on soilborne pests and marketable yield of fresh market tomato (Lycopersicon esculentum) and pepper (Capsicum annuum). Shank injection of fumigants under a virtually impermeable film (VIF) using a novel application apparatus dramatically improved their retention in the soil. Survival of Fusarium oxysporum f. sp. lycopersici in soil declined significantly when fumigation or solarization was combined with VIF compared with either soil disinfestation treatment applied under low-density polyethylene. When compared with an untreated control, significant reductions in yellow nutsedge (Cyperus esculentus), purple nutsedge (C. rotundus), and root-knot nematodes (Meloidogyne spp.) were achieved with a reduced dosage of fumigant when applications were made 7 days after planting beds were covered with VIF. A 7-day delay in fumigant application in beds covered by low-density polyethylene significantly increased marketable yield of pepper when compared with an untreated control. The results demonstrate that chemical and nonchemical soil disinfestation methods can be combined with novel application technology and procedures to improve their spectrum of pest control and reduce fumigant application rates.
\end{abstract}

Additional keywords: methyl bromide, under bed fumigation

The humid, subtropical climate of Florida is host to a number of soilborne plant pests limiting the commercial production of fresh market tomato (Lycopersicon esculentum) and pepper (Capsicum annuum). Major soilborne diseases include Fusarium wilt and crown rot of tomato (Fusarium oxysporum f. sp. lycopersici and $F$. oxysporum f. sp. radicis-lycopersici), southern blight (Athelia rolfsii), Phytophthora blight (Phytophthora capsici), and root rot caused by several Pythium spp. Both crops are affected by several species of root knot nematode (Meloidogyne spp.). Weed pests are also extremely important, of which yellow nutsedge (Cyperus esculentus) and purple nutsedge (C. rotundus) are the most difficult to control.

Corresponding author: D. O. Chellemi E-mail: dchellemi@ushrl.ars.usda.gov

Mention of a trademark, warranty, proprietary product, or vendor does not constitute a guarantee by the U.S. Department of Agriculture and does not imply its approval to the exclusion of other products or vendors that also may be suitable.

Accepted for publication 10 January 2006.

\section{DOI: 10.1094/PD-90-0668}

This article is in the public domain and not copyrightable. It may be freely reprinted with customary crediting of the source. The American Phytopathological Society, 2006.
Florida is the leading producer of fresh market tomato and pepper in the United States (25). Despite intense efforts to find a suitable replacement, preplant soil fumigation with methyl bromide is still considered critical for the control of soilborne pests in fresh market pepper and tomato (30), and Florida growers account for $8 \%$ of the global consumption of methyl bromide (29). Traditionally, mixtures of methyl bromide and chloropicrin (Pic) are shank injected into the soil as it is gathered and pressed into planting beds ( 0.75 to $0.90 \mathrm{~m}$ wide by 15 to $20 \mathrm{~cm}$ high) that are immediately covered with polyethylene plastic $(5,21)$. The plastic is left in the field to function as mulch. Fumigants are injected at a depth of 15 to $20 \mathrm{~cm}$ using three chisels spaced $30 \mathrm{~cm}$ apart.

Preliminary studies indicated the absence of a "stand alone" replacement chemical that could achieve a spectrum of pest control similar to that of methyl bromide while maintaining a high level of marketable yields (26). A mixture of the soil fumigants 1,3-dichloropropene (1,3-D) and Pic and an herbicide (pebulate) had been identified as providing pest control and marketable yields similar to those of methyl bromide for tomato production $(14,17,20)$. Pebulate was required to control yellow and purple nutsedge. However, pebulate is phytotoxic to pepper and is no longer registered for use on tomato. 1,3-D is a restricted use pesticide due to its high acute inhalation toxicity and carcinogenicity (8). Concerns regarding atmospheric emissions prompted a suspension of the use of 1,3-D in California between 1990 and $1994(3,4)$ and requirements for the use of personal protective equipment by workers in the field during its application. To ensure that chemical fumigants are used in the most effective, economical, and environmentally sound way, soil disinfestation programs must be developed that improve their spectrum of pest control and minimize their impact on the environment.

Combining chemical and nonchemical pest management procedures can improve the performance of soil fumigants. For example, the effectiveness of metam sodium was improved by combining its application with soil solarization or biocontrol agents $(2,10,11)$. Application procedures and technology can be developed or modified to minimize worker exposure and fumigant emissions while maintaining levels of pest control similar to methyl bromide. For California strawberry production, drip application methods were modified to permit the application of 1,3-D and Pic under virtually impermeable films (VIF), resulting in control of soilborne pests and yields similar to methyl bromide while simultaneously reducing ambient emissions and worker exposure to fumigants (1). Unfortunately, many Florida growers do not have access to drip irrigation technology. To permit fumigation of existing raised, plastic mulched beds in the absence of drip irrigation systems, a novel apparatus referred to as an under bed fumigator was developed (6). The objective of the current research was to investigate different combinations and application sequences of soil fumigation using a mixture of 1,3-D and Pic, soil solarization, and plastic films for their effects on soilborne pests and marketable yield of fresh market tomato and pepper in Florida.

\section{MATERIALS AND METHODS}

Soils. Field experiments were conducted at the USDA, ARS Header Canal Farm in St. Lucie County, FL. Prior to 2000, the farm was in commercial tomato production using conventional methods including annual soil fumigation using a mixture of methyl bromide and Pic. The soil type was a Riviera fine sand (loamy, siliceous, hyperthermic, Arenic Glossaqualfs). Soil organic matter was $1.7 \%$; soil $\mathrm{pH} 7.4$; and soil texture was $96 \%$ sand, $2 \%$ silt, and $2 \%$ 
clay. Soil moisture at the initiation of experiments ranged from 6.7 to $9.0 \%$ by weight.

Fall 2001 experiment. Eight treatments were arranged in a randomized complete block design with four replications per treatment and included: 1, an untreated control covered by white low density polyethylene (LDPE); 2, fumigation under white LDPE; 3, fumigation under black VIF; 4, delayed fumigation under black VIF; 5, soil solarization under clear LDPE; 6 , solarization under clear LDPE followed by fumigation; 7 , solarization under clear VIF; and 8, solarization under clear VIF followed by fumigation. Properties of the plastic films are listed in Table 1.

The soil solarization period was terminated after 7 days by painting the plastic with a white latex paint (Kool Grow, Gainesville, FL). The black VIF was also painted white to ensure uniform growing conditions during the experiment. The fumigant was a $61 \%: 35 \%$ mixture of 1,3D:Pic (Telone C-35, Dow AgroSciences, Indianapolis, IN) and was applied at 327 liters $\mathrm{ha}^{-1}$ using an under bed fumigator (6). The delayed fumigation treatment was applied 7 days after the plastic-mulched beds were formed.

Each replicate plot was $30 \mathrm{~m}$ in length and consisted of a single raised bed. Bed dimensions were $90 \mathrm{~cm}$ wide and $20 \mathrm{~cm}$ high and were arranged on 2-m row centers. Fertilizer was incorporated into the beds at $252 \mathrm{~kg} \mathrm{~N} \mathrm{ha}^{-1}$ and $252 \mathrm{~kg} \mathrm{~K} \mathrm{ha}^{-1}$ during their preparation. Subsurface (seepage) irrigation was provided, and plants were maintained according to standard commercial production practices (21). Beds were prepared and the plastic films applied on 20 August. Treatments 2 and 3 were fumigated on 20 August. Treatments 4, 6, and 8 were fumigated on 27 August. On 13 September, 50 tomato (cultivar Florida-91) and 50 pepper (cultivar Enterprise) seedlings were transplanted into the center of the beds at $55-\mathrm{cm}$ spacing.

Fall 2002 experiment. Eight treatments were arranged in a randomized complete block design with four replications per treatment. Treatments were: 1, control covered by white LDPE; 2, fumigation under white LDPE; 3, delayed fumigation under white LDPE; 4, fumigation under white VIF; 5, delayed fumigation under white VIF; 6 , soil solarization under clear LDPE; 7, solarization under clear LDPE followed by fumigation; and 8 , solarization under clear VIF followed by fumigation.

The soil solarization period was terminated after 7 days by painting the plastic white. The fumigant was Telone C-35 applied at 327 liters ha $^{-1}$ using the under bed fumigator. The delayed fumigation treatment was applied 7 days after the plastic-mulched beds were formed. Plot size, bed dimensions, fertilizer rates, and production practices were identical to those of the Fall 2001 experiment. Beds were prepared and the plastic films applied on 19 August. Treatments 2 and 4 were fumigated on 19 August. Treatments 3, 5, 7 , and 8 were fumigated on 26 August. On 10 September, 50 tomato (cultivar Florida47) and 50 pepper (cultivar Enterprise) seedlings were transplanted into the beds.

Reduced fumigant dosage experiment. In fall of 2002, an experiment was conducted to identify optimum combinations of soil disinfestation treatments. The fumigant used was Telone-C35. Eight treatments were arranged in a randomized complete block design with four replications per treatment and included: 1 , white LDPE; 2, fumigant applied at 93.2 liters ha $^{-1}$ under white VIF; 3, fumigant applied at 186.4 liters ha $^{-1}$ under white VIF; 4, fumigant applied at 279.6 liters $\mathrm{ha}^{-1}$ under white VIF; 5, solarization under clear VIF; 6, fumigant applied at 93.2 liters ha ${ }^{-1}$ under clear VIF after solarization; 7, fumigant applied at 186.4 liters ha $^{-1}$ under clear VIF after solarization; and 8, fumigant applied at 279.6 liters $^{h^{-1}}$ under clear VIF after solarization. Fumigants were applied and the solarization period terminated 7 days after the plastic-mulched beds were established.

Plot size, bed dimensions, fertilizer rates, and production practices were identical to those of the Fall 2001 experiment. Beds were prepared and the plastic films applied on 19 August. Treatments were fumigated on 26 August. On 10 September, 50 tomato (cultivar Florida-47) and 50 pepper (cultivar Enterprise) seedlings were transplanted into the beds.

Pathogen and inoculum preparation. To measure the effect of soil disinfestation treatments on pathogen survival in the soil, bags containing $F$. oxysporum f. sp. lycopersici Race 3 were buried in the soil in the Fall 2001 and Fall 2002 experiments. A single-spore isolate was obtained from a plant with symptoms of Fusarium wilt of tomato in St. Lucie County, FL. Five 3$\mathrm{mm}$ disks of an 8-day-old colony growing on potato dextrose agar were used to inoculate $300-\mathrm{ml}$ flasks containing $20 \mathrm{~g}$ of hard winter wheat seed that had been soaked overnight in $25 \mathrm{ml}$ of deionized water. The flasks were maintained at $25^{\circ} \mathrm{C}$ and shaken vigorously every 3 days to ensure uniform growth of the fungus. After 14 to 21 days, $10 \mathrm{~g}$ of infested wheat seed was removed, finely ground, and mixed with $90 \mathrm{~g}$ of pasteurized soil from the farm site. Two grams of the wheat seed/soil mixture were placed into sealed bags con-

Table 1. Plastic films used in the field experiments

\begin{tabular}{ll}
\hline Film $^{\mathbf{z}}$ & Properties and brand name / manufacturer \\
\hline White LDPE & $30 \mu \mathrm{m}$, embossed, co-extruded white-black / Plaint, Schaumburg, IL \\
Clear LDPE & $30 \mu \mathrm{m}$, smooth, Polydak film / Polyon Barkai, Kibbutz Barkai, Israel \\
Clear VIF & $35 \mu \mathrm{m}$, smooth, Hytibarrier Flex / Klerks, Hoogstraten, Belgium \\
Black VIF & $35 \mu \mathrm{m}$, smooth, Hytibarrier Flex / Klerks \\
White VIF & $35 \mu \mathrm{m}$, smooth, tri-extruded white-black, Hytibarrier Flex /Klerks \\
\hline
\end{tabular}

${ }^{\mathrm{z}}$ LDPE, low density polyethylene; VIF, virtually impermeable film. structed from 10- $\mu \mathrm{m}$-diameter nylon filters (Spectra/Mesh, Spectrum Laboratories, Inc., Rancho Dominguez, CA). Bags were buried in the center of the raised beds prior to being covered by the plastic mulch and application of the soil treatments. One bag was buried in each plot. The bags were removed after 28 to 30 days, and soil was plated onto a medium selective for $F$. $o x$ ysporum to determine the inoculum density (18). Inoculum bags were buried in the Fall 2001 and 2002 experiments.

Assessment of pest control in the field. A mixture of yellow and purple nutsedge was present in all experiments. Nutsedge control was measured by counting the number of plants emerging through the plastic over a 12-m-long section of the row. On tomato, the incidence of Fusarium wilt and southern blight, caused by Athelia rolfsii, was assessed after the first harvest. On pepper, the incidence of southern blight and Pythium root rot was assessed. Visual diagnosis of disease symptoms was confirmed by isolation and identification of the causal agent. Root systems from five plants in each replicate plot were removed following the final harvest and rated for root galling by Meloidogyne species on a 0 to 5 scale $(28)$ in which $0=$ no galls per root system, $1=$ one to two galls per root system, $2=$ three to 10 galls per root system, $3=11$ to 30 galls per root system, $4=$ 31 to 100 galls per root system, and $5=$ more than 100 galls per root system. The density of plant parasitic nematodes in soil was determined in the reduced fumigant dosage experiment only. Soil samples for nematode analysis were collected by removing and combining soil cores $2.5 \mathrm{~cm}$ wide and $20 \mathrm{~cm}$ deep from the root zone of were extracted from $100-\mathrm{cm}^{3}$ soil subsamples with a modified sieving and centrifugation procedure (16) and then counted. Twelve contiguous plants in the center of each replicate plot were harvested. Fruit were sorted as marketable and unmarketable based upon size and cosmetic appearance.

Measurement of fumigant concentration and soil temperatures in the bed. The concentration of 1,3-D and Pic in the soil atmosphere was measured by removing a $2.5 \times 12.5 \mathrm{~cm}$ core of soil from the center of the bed and sampling the subsequent airspace using a GasTec Model GV100 Gas Sampling Pump (Sensidyne Inc., Clearwater, FL) with Gastec 132HA and 139 trichloroethylene detector tubes (Gaseach of six plants per plot. Nematodes 
Tec Corp., Ayase-City, Japan). The integrity of the plastic mulch was not disturbed except where the soil core was removed. Concentrations were adjusted using correction factors recommended by the manufacturer. Samples were collected from two replicate plots in the delayed fumigation treatments using clear LDPE and clear VIF in the fall 2001 experiment and represented as the average of the two plots. Samples were collected from two replicate plots in the white LDPE and white VIF fumigation treatments in the Fall 2002 experiment. Data were expressed as the average of the two replicate plots for each treatment measured. Hourly changes in soil temperatures were monitored during the solarization periods at 5 and $15 \mathrm{~cm}$ depths using thermocouple sensors connected to electronic data loggers (Onset Computer Corp, Bourne, MA). Maximum soil temperatures and the number of degree hours above $40^{\circ} \mathrm{C}$ were measured in two replicate plots of the clear VIF and white LDPE treatments in the Fall 2001 experiment and two replicates of the clear and white VIF treatments in the Fall 2002 experiment. Data were expressed as the average of the two replicate plots for each treatment measured.

Statistical analysis. Disease incidence data were transformed using the arcsine transformation $\left(\sin ^{-1}\right.$ square root $x$ ) prior to analysis. Propagule counts for $F$. oxysporum f. sp. lycopersici and nematode counts were $\log$-transformed $(\log 10[x+$ 1]) prior to analysis. Analysis of variance was performed using the generalized linear models procedure in STATISTICA (Statsoft, Tulsa, OK). Fisher's protected least significance procedure was used to compare treatment means for all variables measured in the Fall 2001 and 2002 experiments except $F$. oxysporum f. sp. lycopersici propagule counts, where treatment means and $95 \%$ confidence limits were graphically depicted. In the reduced fumigant dosage study, data were analyzed as $2 \times 4$ factorial with two plastic types and four fumigant application rates. The dose-response relationship between fumigant dose and marketable yield was analyzed using a quadratic function in SigmaPlot (SPSS, Inc., Chicago, IL).

\section{RESULTS}

Fumigant concentrations and soil temperatures. In the Fall 2001 experiment, concentrations of 1,3-D and Pic in the soil reached a maximum of $300 \mathrm{ppm}$ after 2 days and declined to undetectable levels by 7 days after application under clear LDPE. Under clear VIF, 1,3-D and Pic concentrations reach a maximum of $800 \mathrm{ppm}$ at 3 days after application. At 14 days after application, concentrations of 1,3-D and Pic were undetectable under the clear VIF.

In the Fall 2002 experiment, the concentration of 1,3-D and Pic in the soil underneath the white LDPE reached a maximum of 225 ppm after 2 days, declined to 100 ppm by day 3 , and was undetectable 7 days after application (Fig. 1). Under the white VIF, the fumigant concentration reached a maximum of 900 ppm 4 days after application. At 10 days, fumigant concentration under VIF was still greater than the maximum concentration achieved under LDPE. A trace amount of fumigant was still detected 18 days after application.

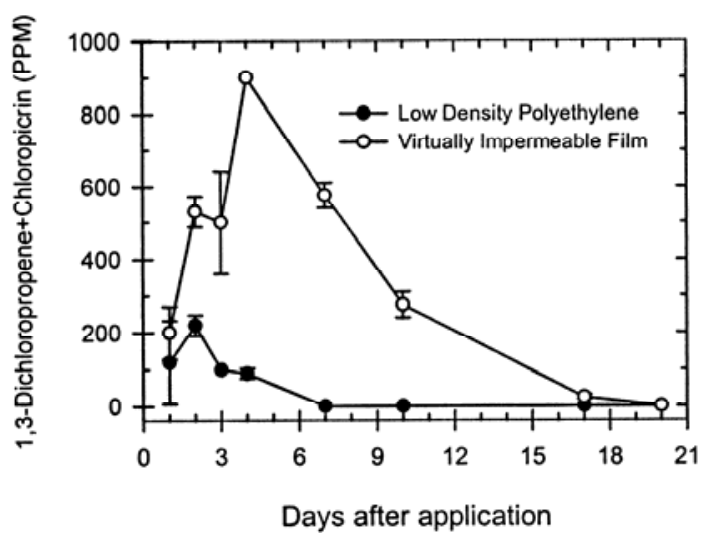

Fig. 1. Concentration of 1,3-dichloropropene and chloropicrin in the soil atmosphere under raised, plastic-mulched beds following application of a 61:35 mixture at 327 liters ha ${ }^{-1}$ using the under bed fumigator. Samples collected at $0-$ to $12-\mathrm{cm}$ depths in the center of the beds.

Table 2. Soil temperatures under white low density polyethylene (LDPE) and clear virtually impermeable film (VIF) during a 7-day solarization period in August

\begin{tabular}{|c|c|c|c|c|c|c|c|c|}
\hline \multirow[b]{3}{*}{ Year } & \multicolumn{4}{|c|}{ Maximum temperatures $\left({ }^{\circ} \mathbf{C}\right)$} & \multicolumn{4}{|c|}{ Degree hours $>40^{\circ} \mathrm{C}$} \\
\hline & \multicolumn{2}{|c|}{ Clear VIF } & \multicolumn{2}{|c|}{ White LDPE } & \multicolumn{2}{|c|}{ Clear VIF } & \multicolumn{2}{|c|}{ White LDPE } \\
\hline & $5 \mathrm{~cm}$ & $15 \mathrm{~cm}$ & $5 \mathrm{~cm}$ & $15 \mathrm{~cm}$ & $5 \mathrm{~cm}$ & $15 \mathrm{~cm}$ & $5 \mathrm{~cm}$ & $15 \mathrm{~cm}$ \\
\hline 2001 & 49.6 & 42.0 & 40.6 & 37.4 & 197.6 & 16.2 & 1.0 & 0.0 \\
\hline 2002 & 53.5 & 42.0 & 39.7 & 36.1 & 199.5 & 5.8 & 0.0 & 0.0 \\
\hline
\end{tabular}

At a 5-cm depth, maximum soil temperatures were $9^{\circ} \mathrm{C}$ and $13.8^{\circ} \mathrm{C}$ higher under clear VIF than under white LDPE in 2001 and 2002, respectively (Table 2). At a $15-\mathrm{cm}$ depth, the maximum soil temperature was $4.6^{\circ} \mathrm{C}$ and $3.6^{\circ} \mathrm{C}$ higher under clear VIF than white LPEP in 2001 and 2002, respectively. Under clear VIF, the number of degree hours accumulated at 5 $\mathrm{cm}$ was similar in both years. At $15 \mathrm{~cm}$, three times as many degree hours were accumulated under VIF in 2001.

Survival of $F$. oxysporum f. sp. lycopersici. In the absence of a soil disinfestation treatment (white-LDPE), the density of $F$. oxysporum f. sp. lycopersici in the buried inoculum bags ranged between $10^{5}$ and $10^{6}$ propagules per gram of soil (Fig. 2 ). In both years, application of the fumigant under white LDPE failed to reduce inoculum densities when compared to the untreated control (white LDPE). In 2001, fumigation under black VIF reduced inoculum only when the application was made 7 days after the plastic was placed in the field. In 2002, fumigation under white VIF reduced inoculum to undetectable levels at both fumigant application dates. In 2 years of tests, solarization under clearVIF for 7 days then fumigation resulted in significantly lower inoculum densities compared to white LDPE only. In 2001, solarization under clear-VIF for 7 days then fumigation also resulted in significantly lower inoculum density compared with fumigation under black-VIF. Although not tested in both years, solarization under clear-VIF alone (2001) reduced inoculum density compared with solarization under clear-LDPE and fumigation under white LDPE and white VIF.

Emergence of nutsedge. In the absence of soil disinfestation (white LDPE), the number of nutsedge shoots emerging through the plastic mulch was 22 and 16 per meter of row in 2001 and 2002, respectively (Fig. 3). Populations were a mixture of yellow and purple nutsedge. When compared with untreated soil covered by white LDPE, significant reductions in the emergence of nutsedge through the plastic mulched beds occurred in all soil disinfestation treatments except solarization under clear LDPE. In 2001, nutsedge emergence was reduced to less than 1 per meter of row when the fumigant was applied after solarization. In 2002, nutsedge was reduced to less than 1 per meter of row in all treatments where the fumigant was applied under VIF.

In the reduced fumigant dosage experiment, the effect of soil fumigation on nutsedge emergence was significant when compared with the untreated control (Table 3). Soil solarization for a 7-day period did not affect nutsedge emergence, and no interaction was observed between solarization and fumigation (Table 3). Significant control of nutsedge was achieved with the lowest fumigant dose (Table 4). 
Disease control. The incidence of Fusarium wilt and southern blight of tomato was less than $1 \%$ in all experiments. Pythium root rot of pepper was observed in five of the eight treatments in the 2001 experiment, but the differences in disease were not significant. In the Fall 2002 experiment, the incidence of soilborne disease on pepper was less than $1 \%$. In the reduced fumigant dosage experiment, southern blight was observed on pepper. Soil solarization for a 7-day period did not affect disease while the effect of fumigation was significant at $P=0.08$ (Table 3). Disease was reduced to $1 \%$ or less in the treatments receiving the higher doses of fumigants (Table 4).

Nematode control. Gall formation on roots from Meloidogyne spp. was not observed on tomato and pepper in the Fall 2000 and 2001 experiments. In the reduced fumigant dosage experiment, significant root galling was observed on tomato but not pepper. Fumigation under VIF reduced the density of Meloidogyne spp. and the severity of root galling (Table 3 ). Solariza- tion did not affect nematode density or root galling and no interaction was observed. The low fumigant application dose was effective in reducing the density of Meloidogyne spp. and the severity of root galling under VIF (Table 4).

Marketable yield. In the Fall 2001 experiment, marketable yield of pepper ranged from $1.3 \mathrm{~kg}$ per plant in the treatment with white LDPE and no fumigant to $1.9 \mathrm{~kg}$ per plant in the treatment where fumigation followed a 7-day solarization period under clear VIF (Fig. 4). The differences in treatment means were not significant $(P=0.27)$. On tomato, marketable yield ranged from $3.5 \mathrm{~kg}$ per plant in the treatment with white LDPE and no fumigant to $4.7 \mathrm{~kg}$ per plant in the treatment where fumigation followed a 7-day solarization period under clear VIF. Differences in the treatment means were significant at $P=0.09$. In the fall 2002 experiment, marketable yield of pepper ranged from $0.6 \mathrm{~kg}$ per plant in the treatment with white LDPE and no fumigant to $2.3 \mathrm{~kg}$ per plant in the treatment where fumigation under white VIF was delayed for 7 days (Fig. 5). Differences in treatment means were significant on pepper $(P$ $=0.01)$. On tomato, marketable yield ranged from $3.8 \mathrm{~kg}$ per plant in the treatment with white LDPE and no fumigant to $5.0 \mathrm{~kg}$ per plant in the treatment where fumigation under white VIF was delayed by a 7-day period. No differences in treatment means were observed on tomato $(P=0.45)$.

In the reduced dosage experiment, a 7day soil solarization period did not affect the marketable yield of pepper or tomato (Table 3). However, the effect of soil fumigation on yield was significant. A quadratic effect was used to describe the relationship between fumigant dose and marketable yield with coefficient of determination $\left(r^{2}\right)$ values ranging from 0.99 for tomato to 0.86 for pepper (Fig. 6). Using the regression coefficients derived from the analysis, maximum yields on pepper and tomato were projected to occur at a fumigant dose of 190 and 180 liter $\mathrm{ha}^{-1}$, respectively.
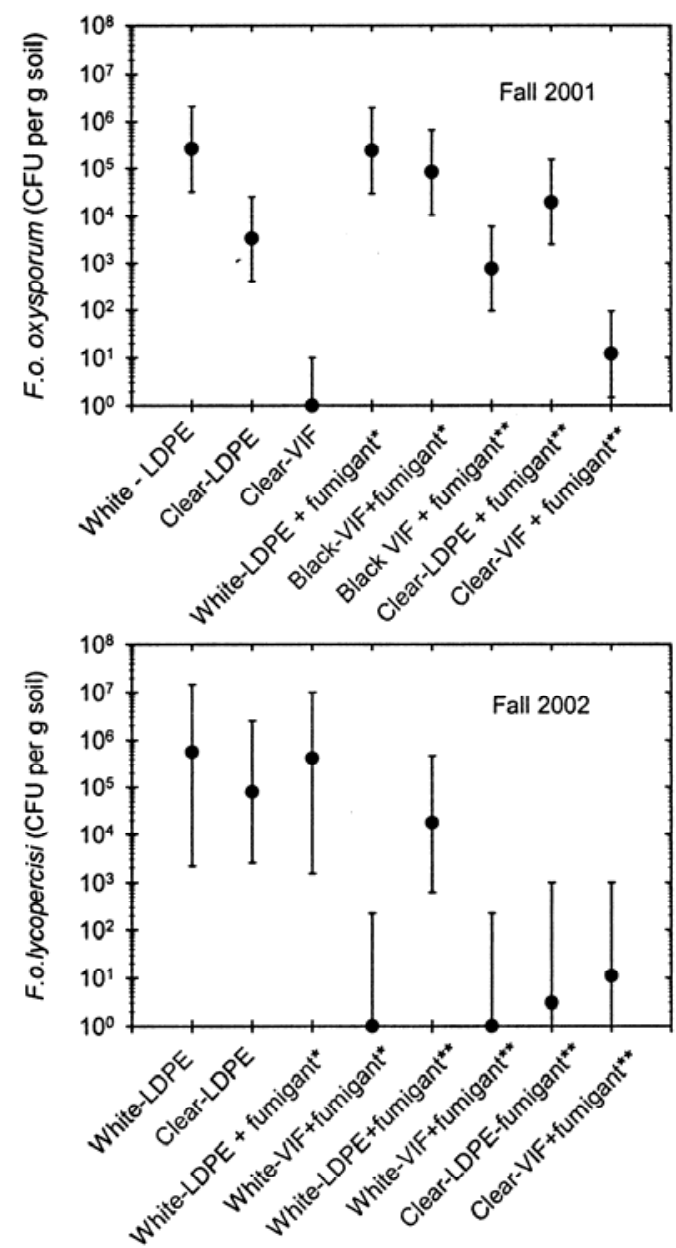

Fig. 2. Effect of soil disinfestation treatments on survival of Fusarium oxysporum $\mathrm{f}$. sp. lycopersici in soil. LDPE $=$ low density polyethylene film, VIF = virtually impermeable film. Soil under clear plastic was solarized for 7 days. $* 1,3$-dichloropropene + chloropicrin (61\%:35\%) applied the same day plastic-mulched beds were prepared. $* * 1,3$-dichloropropene + chloropicrin (61\%:35\%) applied 7 days after plastic-mulched beds were prepared. Bars represent $95 \%$ confidence intervals around the mean of four replications.
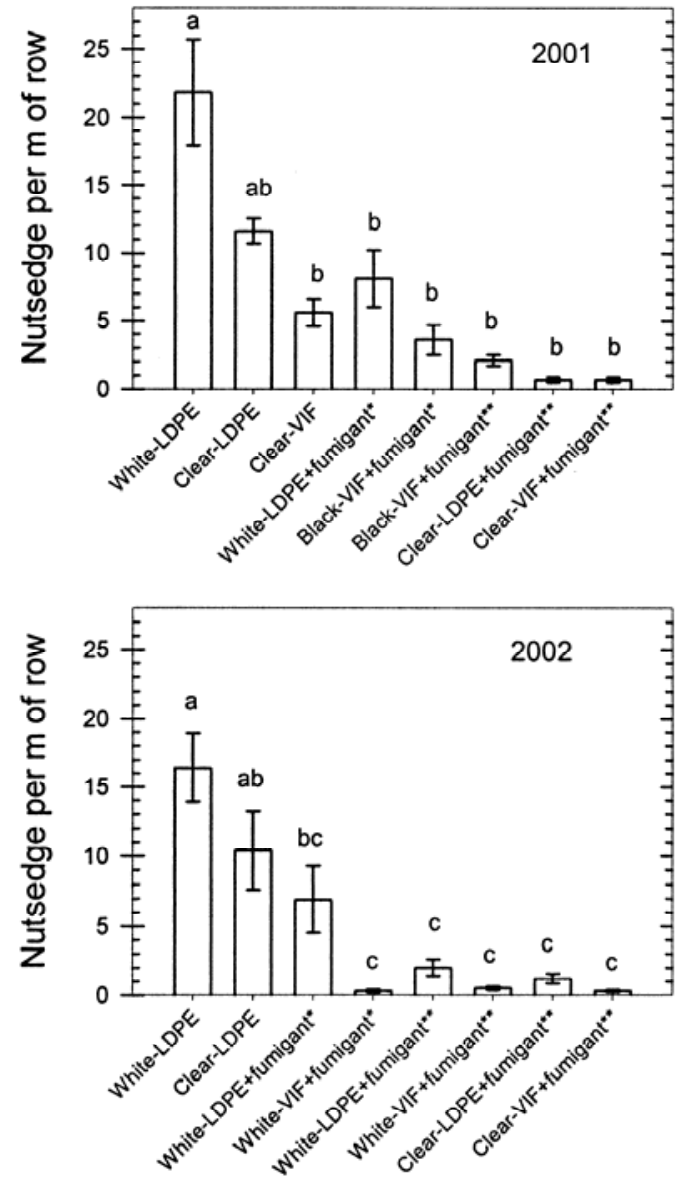

Fig. 3. Effect of soil disinfestation treatments on nutsedge emerging through plastic 32 to 37 days after transplanting. LDPE = low density polyethylene film, VIF = virtually impermeable film. Soil under clear plastic was solarized for 7 days. *1,3-dichloropropene + chloropicrin (61\%:35\%) applied the same day plastic-mulched beds were prepared. **1,3-dichloropropene + chloropicrin (61\%:35\%) applied 7 days after plastic-mulched beds were prepared. Bars represent standard error. Similar letters above the error bars indicate no significant difference at $P$ $\leq 0.05$. 
Table 3. Significance levels $(P)$ of soil solarization and/or fumigation using a 62:35 mixture of 1,3dichloropropene and chloropicrin on control of soilborne pests and yield of fresh market pepper and tomato

\begin{tabular}{lccc}
\hline & \multicolumn{3}{c}{ Significance level $(\boldsymbol{P})$} \\
\cline { 2 - 4 } Variable & Solarization $^{\mathbf{w}}$ & Fumigant $^{\mathbf{x}}$ & Interaction \\
\hline Cyperus spp. per m row & 0.18 & $<0.01$ & 0.14 \\
Athelia rolfsii on pepper & 0.21 & 0.08 & 0.21 \\
Root gall ratings ${ }^{\mathrm{y}}$ on tomato & 0.80 & $<0.01$ & 0.99 \\
Meloidogyne species ${ }^{\mathrm{z}}$ on tomato & 0.62 & $<0.01$ & 0.79 \\
Marketable yield of tomato & 0.96 & 0.05 & 0.46 \\
Marketable yield of pepper & 0.46 & $<0.01$ & 0.55
\end{tabular}

${ }^{\text {w}}$ Soil solarization conducted for 7 days under a clear virtually impermeable film. Nonsolarization treatments used white VIF.

${ }^{\mathrm{x}}$ Fumigant applied 7 days after plastic application at 0, 94, 187, or 280 liters $\mathrm{ha}^{-1}$ using the under bed fumigator.

${ }^{\mathrm{y}}$ Estimates of the number of galls per root system using a scale of 0 to 5 in which $0=$ no galls and $5=$ more than 100 galls (28).

${ }^{\mathrm{z}}$ Density of nematodes per $100 \mathrm{~cm}^{3}$ of soil.

Table 4. Effect of reduced fumigant dosage on the density of Meloidogyne spp., root galling of tomato, and Cyperus spp. emerging through plastic mulched beds

\begin{tabular}{|c|c|c|c|c|}
\hline Fumigant ${ }^{v}$ & Meloidogyne spp. ${ }^{\mathrm{w}}$ & Gall rating ${ }^{x}$ & Cyperus spp..$^{y}$ & Disease $^{z}$ \\
\hline 0.0 liters ha ${ }^{-1}$ & $1,122.0 \mathrm{a}$ & $2.1 \mathrm{a}$ & $3.2 \mathrm{a}$ & $3 \%$ \\
\hline 93.0 liters ha $^{-1}$ & $4.0 \mathrm{~b}$ & $0.3 \mathrm{~b}$ & $0.5 \mathrm{~b}$ & $7 \%$ \\
\hline 186.0 liters $\mathrm{ha}^{-1}$ & $1.0 \mathrm{~b}$ & $0.0 \mathrm{~b}$ & $0.1 \mathrm{~b}$ & $0 \%$ \\
\hline 279.0 liters $\mathrm{ha}^{-1}$ & $0.0 \mathrm{~b}$ & $0.0 \mathrm{~b}$ & $0.3 \mathrm{~b}$ & $1 \%$ \\
\hline
\end{tabular}

${ }^{v}$ A 62:35 mixture of 1,3-dichloropropene:chloropicrin applied under virtually impermeable film.

${ }^{w}$ Density per $100 \mathrm{~cm}^{3}$ of soil.

${ }^{x}$ Estimates of the number of galls per root system using a scale of 0 to 5 in which $0=$ no galls and $5=$ more than 100 galls.

${ }^{\mathrm{y}}$ Number of shoots per meter of row.

${ }^{\mathrm{z}}$ Incidence of southern blight (Athelia rolfsii) on pepper expressed as a percentage.

\section{DISCUSSION}

Previous studies have demonstrated that control of Verticillium wilt, Cyperus spp., and plant parasitic nematodes was improved when mixtures of methyl bromide + Pic were applied under VIF $(1,12,27)$. However, conflicting results have been reported regarding additional benefits in pest control when 1,3-D + Pic is applied under VIF $(7,15,19)$. In this study, the performance of soil solarization and soil fumigation generally improved when VIF was included in the treatment. This was evidenced by the reduced survival of $F$. oxysporum f. sp. oxysporum in the soil and reduced competition from Cyperus spp., and by the increase in marketable yields of tomato in 2001 and pepper in 2002 with VIF. With the fumigation treatments, improvements in pest control with VIF can be attributed to the increased retention of 1,3$\mathrm{D}+\mathrm{Pic}$ in the soil when compared to fumigation under LDPE. The biocidal effect of fumigants is driven by their concentration and persistence in the soil (24). Increasing the chemical concentration and/or length of time that an organism is exposed to a fumigant will amplify their sensitivity to the chemical. Plastic films constructed from polyethylene are poor physical barriers to 1,3-D and ineffective in reducing atmospheric emissions (13,31). Retention in the soil is dramatically improved when $1,3-\mathrm{D}$ is applied under VIF $(1,6,15)$. In this

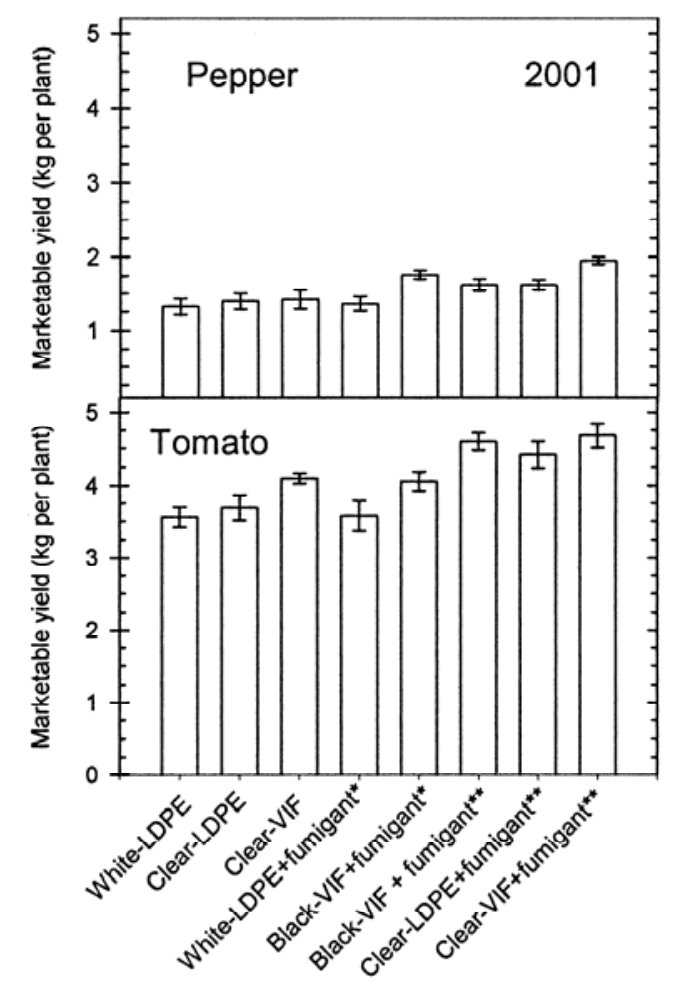

Fig. 4. Effect of soil disinfestation treatment combinations on marketable yield in fall 2001 experiment. LDPE = low density polyethylene film, VIF $=$ virtually impermeable film. Soil under clear films was solarized for 7 days. $* 1,3$-dichloropropene + chloropicrin $(61 \%: 35 \%)$ applied the same day plastic-mulched beds were prepared. $* * 1,3$-dichloropropene + chloropicrin (61\%:35\%) applied 7 days after plastic-mulched beds were prepared. Bars represent standard error.

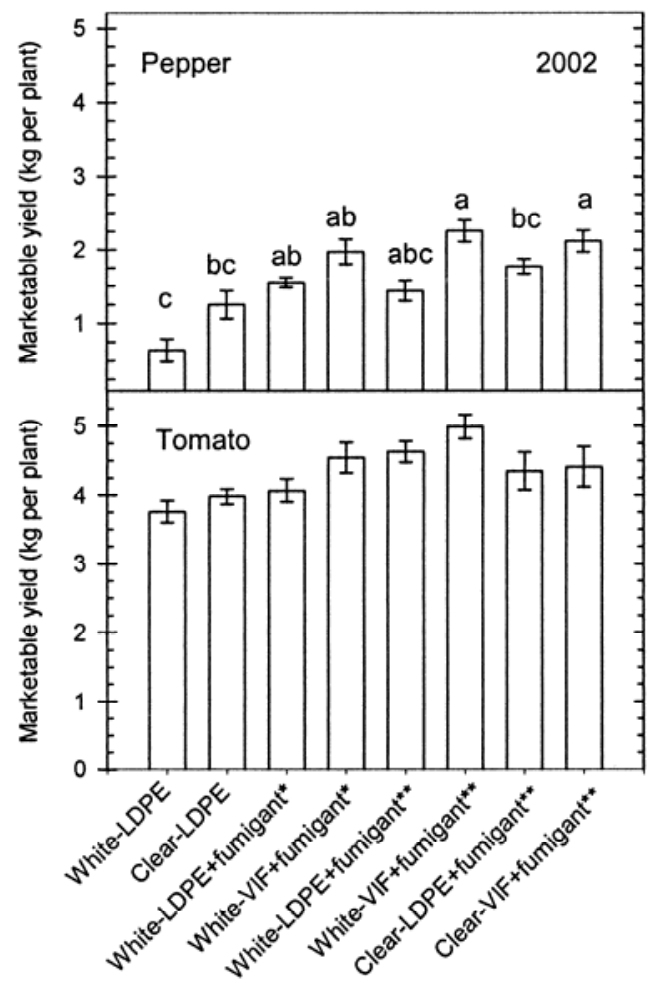

Fig. 5. Effect of treatment combinations on marketable yield in fall 2002 experiment. $\mathrm{LDPE}=$ low density polyethylene film, VIF = virtually impermeable film. Soil under clear films was solarized for 7 days. *1,3dichloropropene + chloropicrin $(61 \%: 35 \%)$ applied the same day plasticmulched beds were prepared. **1,3-dichloropropene + chloropicrin (61\%:35\%) applied 7 days after plastic-mulched beds were prepared. Bars represent standard error. 
study, VIF had an enormous impact on the quantity of 1,3-D and Pic that remained in the soil atmosphere after application. The use of VIF improved the effectiveness of soil solarization, as evidenced by reductions in F. oxysporum f. sp. lycopersici and emerging Cyperus spp. when compared to solarization under LDPE. Hypotheses accounting for the observed differences in pest control include elevated soil temperatures and accumulation of biotoxic volatile compounds under the VIF. This could not be confirmed because direct comparisons of heat accumulation and accumulation of volatile compounds were not conducted between the clear LDPE and the clear VIF.

Pepper is intolerant of yellow nutsedge densities greater than 3 per meter of row (22). Several treatment combinations in this study provided control of Cyperus spp. below that threshold. In 2001, treatments combining solarization with fumigation and the delayed fumigation under black VIF reduced Cyperus spp. counts below 3 per meter of row. In 2002, fumigation under VIF and treatments that combined solarization with fumigation reduced nutsedge counts below 3 per meter of row. Economic control of Cyperus spp. was also achieved under white LDPE when the application of 1,3-D + Pic was delayed for 7 days. In greenhouse studies, tubers of yellow nutsedge that had imbibed water or sprouted were more sensitive to a mixture of 1,3-D and Pic (23). Thus, altering the application sequence to allow tubers to germinate prior to fumigation appears to improve the effectiveness of 1,3-D + Pic.

In general, changing the application sequence of soil fumigants to improve their effectiveness has not been adequately ex- plored. In a study by Eshel et al. (9), fumigation following an 8-day solarization period was more effective than fumigation prior to the initiation of solarization. In this study, fumigation following a 7-day solarization period significantly reduced the survival of $F$. oxysporum f. sp. lycopersici in 2002 but not in 2001. The same treatment combination also reduced the number of emerging nutsedge shoots from 12 to less than 1 per meter of row. In commercial vegetable production systems, this can be accomplished by applying chemical fumigants several days after the plasticmulched beds have been prepared. Delaying the application of fumigants until after the raised, plastic-mulched beds have been prepared creates an opportunity for workers to vacate fields prior to fumigation, further mitigating the risk of human exposure.

This study also demonstrated that the dosage of 1,3-D + Pic can be reduced without compromising the level of pest control using a combination of VIF and delayed fumigant application. Control of Cyperus spp. and Meloidogyne spp. were achieved at an application rate of 93.2 liters $\mathrm{ha}^{-1}$. Maximum yields were obtained at 190 and 180 liters $\mathrm{ha}^{-1}$ for pepper and tomato, respectively. Reducing the dosage of fumigant applied in the field will minimize its impact on the environment and shorten the period of time growers must wait before planting into fumigated soil (plant back interval). The registration label of Telone C-35 requires a specific plant back interval for each 93.2 liters $\mathrm{ha}^{-1}$ of fumigant applied (8). Finally, reducing the fumigant dose will also create cost savings for growers. By optimizing combinations

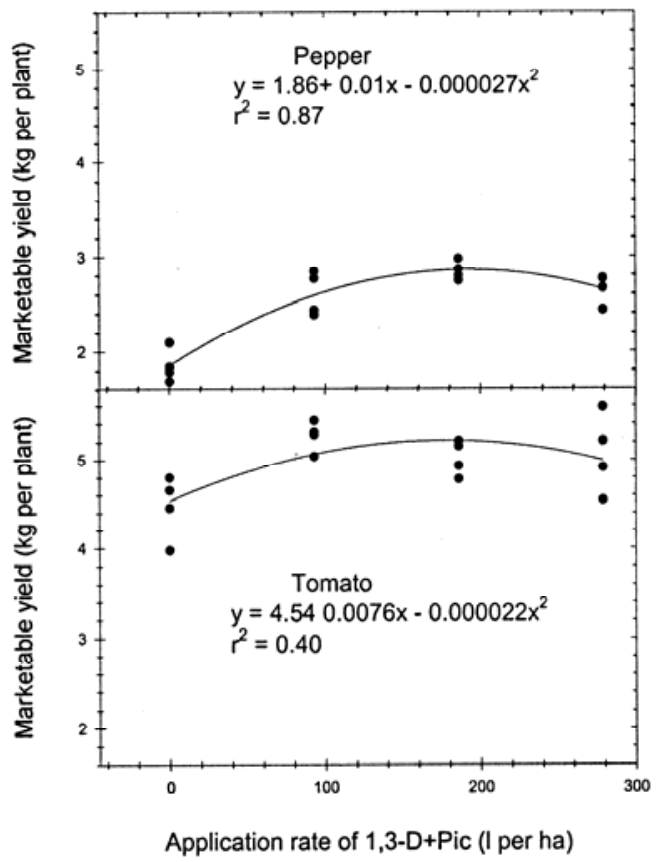

Fig. 6. Relationship between the dosage of 1,3-dichloropropene + chloropicrin (61\%:35\%) and the marketable yield of pepper and tomato. The fumigant was applied under a virtually impermeable film 7 days after the plastic-mulched beds were prepared. of chemical and nonchemical soil disinfestation practices and integrating new technology into the application procedures, this study demonstrated that effective pest control can be achieved using methods that reduce the risk of environmental contamination or human exposure to pesticides.

\section{ACKNOWLEDGMENTS}

We thank Jerry Nance and Tony Weiss of Dow AgroSciences and David Neill and Jock Ivy of Triangle Tomato Company for providing technical assistance and materials.

\section{LITERATURE CITED}

1. Ajwa, H. A., Trout, T., Mueller, J., Wilhelm, S., Nelson, S. D., Soppe, R., and Shatley, D. 2002. Application of alternative fumigants through drip irrigation systems. Phytopathology 92:1349-1355.

2. Ben-Yephet, Y., Melero, D. E., and DeVay, J. M. 1988. Interaction of soil solarization and metham-sodium in the destruction of Verticillium dahilae and Fusarium oxysporum f. sp. vasinfectum. Crop Prot. 7:327-331.

3. California Department of Food and Agriculture. 1990. Use of pesticide suspended by CDFA. News Release 90-45. CDFA, Sacramento, CA.

4. California Department of Pesticide Regulations. 1994. DPR approves limited use of soil fumigant. News Release 94-42. CDFA, Sacramento, CA

5. Cantliffe, D. J., Hochmuth, G. J., Locascio, S. J., Stansly, P. A., Vavrina, C. S., Polston, J. E., Schuster, D. J., Seal, D. R., Chellemi, D. O., and Olson, S. M. 1995. Production of solanacea for fresh market under field conditions: Current problems and potential solutions. Acta Hortic. 414:229-244.

6. Chellemi, D. O., and Mirusso, J. 2004. An apparatus to inject soil fumigants under raised, plastic-mulched beds. Appl. Engineering Agric. 20(5):585-589.

7. Chellemi, D. O., Olson, S. M., Mitchell, D. J., Secker, I., and McSorley, R. 1997. Adaptation of soil solarization to the integrated management of soilborne pests of tomato under humid conditions. Phytopathology 87:250-258.

8. Dow AgroSciences. 2003. Specimen label for Telone C-35. Revised 07-11-03. Dow AgroSciences LLC, Indianapolis, IN.

9. Eshel, D., Gamliel, A., Grinstein, A., Di Primo, P., and Katan, J. 2000. Combined soil treatments and sequence of application in improving the control of soilborne pathogens. Phytopathology 90:751-757.

10. Frank, Z. R., Ben-Yephet, Y., and Katan, J. 1986. Synergistic effect of metham and solarization in controlling delimited shell spots of peanut pods. Crop Prot. 5:199-202.

11. Fravel, D. R. 1996. Interaction of biocontrol fungi with sublethal rates of metham sodium for control of Verticllium dahliae. Crop Prot. 15:115-119.

12. Gamliel, A., Grinstein, A., Peretz, Y., Klein, L., Nachmias, A., Tsror, L., Livescu, L., and $\mathrm{Ka}-$ tan, J. 1997. Reduced dosage of methyl bromide for controlling Verticillium wilt of potato in experimental and commercial plots. Plant Dis. 81:469-474.

13. Gan, J., Yates, S. R., Wang, D., and Ernst, E. F. 1998. Effect of application methods on 1,3dichloropropene volatilization from soil under controlled conditions. J. Environ. Qual. 27:432-438.

14. Gilreath, J. P., Noling, J. W., Locascio, S. J., and Chellemi, D. O. 1999. Effect of methyl bromide, 1,3-dichloropropene + chloropicrin with pebulate and soil solarization on soilborne pest control in tomato followed by double 
cropped cucumber. Proc. Fla. State Hortic. Soc. 112:292-297.

15. Hochmuth, R. C., Davis, W. E., Stall, W. M., Simonne, E. H., Weiss, A. W., Nance, J., and Mirusso, J. 2003. Effect of 1,3-dichloropropene and chloropicrin on purple nutsedge (Cyperus rotundus L.) control under two mulches and two application methods. Proc. Fla. State Hortic. Soc. 116:164-167.

16. Jenkins, W. R. 1964. A rapid centrifugalflotation technique for separating nematodes from soil. Plant Dis. Rep. 48:692.

17. Jones, J. P., Gilreath, J. P., Overman, A. J., and Noling, J. W. 1995. Control of soil-borne diseases of mulched tomato by fumigation. Proc. Fla. State Hortic. Soc. 108:201-203.

18. Komada, H. 1975. Development of a selective medium for quantitative isolation of Fusarium oxysporum from natural soil. Rev. Plant Prot. Res. 8:114-125.

19. Locascio, S. J., Dickson, D. W., and Rosskopf, E. 2002. Alternative fumigants applied with standard and virtually impermeable mulches for tomato. Proc. Fla. State Hortic. Soc. 115:192-194.
20. Locascio, S. J., Gilreath, J. P., Dickson, D. W., Kucharek, T. A., Jones, J. P., and Noling, J. W. 1997. Fumigant alternatives to methyl bromide for polyethylene-mulched tomato. HortScience 32:1208-1211.

21. Maynard, D. N., and Olson, S. M. 2002. Vegetable Production Guide for Florida. University of Florida, IFAS Publ. HS710, Gainesville.

22. Motis, T. N., Locascio, S. J., and Gilreath, J. P. 2001. Yellow nutsedge interference effects on fruit weight of polyethylene-mulched bell pepper. Proc. Fla. State Hortic. Soc. 114:268271.

23. Motis, T. N., Locascio, S. J., and Gilreath, J. P. 2002. Efficacy of 1,3-dichloropropene + chloropicrin and metam-Na on yellow nutsedge tubers planted at varying growth stages. Proc. Fla. State Hortic. Soc. 115:189-192.

24. Munnecke, D. E., and Van Gundy, S. D. 1979. Movement of fumigant in soil, dosage response and differential effects. Annu. Rev. Phytopathol. 17:405-429.

25. National Agricultural Statistics Service (NASS). 2002. Florida Facts. Online publication.
26. Noling, J. W., and Gilreath, J. P. 2000. Methyl bromide: Progress and problems identifying alternatives. Citrus \& Vegetable Magazine, June 2000, pages A1-A15.

27. Santos, B., Gilreath, J., and Motis, T. 2005 Managing nutsedge and sting nematode with reduced methyl bromide plus chloropicrin rates under virtually impermeable films in pepper. HortTechnology 15(3):569-599.

28. Taylor, A. L., and Sasser, J. N. 1978. Biology, identification and control of root-knot nematodes (Meloidogyne species). North Carolina State University, Raleigh.

29. U.S. Environmental Protection Agency. 1997. Methyl bromide use, United States Environmental Protection Agency. Online publication.

30. U.S. Environmental Protection Agency. 2003 Environmental News: Friday, February 7 2003. U.S. Government nominates critical use exemptions for methyl bromide. Online publication.

31. Yates, S. R., Gan, J., Papiernik, S. K., Dungan, R., and Wang, D. 2002. Reducing fumigan emissions after soil application. Phytopathology 92:1344-1348. 